\title{
Heat shock decreases the embryonic quality of frozen-thawed bovine blastocysts produced in vitro
}

\author{
Miyuki MORI'), Takeshi HAYASHI'), Yoshihiro ISOZAKI'), Naoki TAKENOUCHI') and \\ Miki SAKATANI') \\ 1) Fukuoka Agriculture and Forestry Research Center, Fukuoka 818-8549, Japan \\ 2) Livestock and Grassland Research Division, Kyushu Okinawa Agricultural Research Center, National Agriculture and \\ Food Research Organization (NARO), Kumamoto 861-1192, Japan
}

\begin{abstract}
In this study, the effect of heat shock on frozen-thawed blastocysts was evaluated using in vitro-produced (IVP) bovine embryos. In experiment 1 , the effects of $6 \mathrm{~h}$ of heat shock at $41.0 \mathrm{C}$ on fresh blastocysts were evaluated. HSPA1A expression as a reflection of stress was increased by heat shock $(\mathrm{P}<0.05)$, but the expressions of the quality markers $I F N T$ and POU5F1 were not affected. In experiment 2, frozen-thawed blastocysts were incubated at $38.5 \mathrm{C}$ for $6 \mathrm{~h}$ (cryo-con) or exposed to heat shock at $41.0 \mathrm{C}$ for $6 \mathrm{~h}$ (cryo-HS). Then, blastocysts were cultured at $38.5 \mathrm{C}$ until $48 \mathrm{~h}$ after thawing (both conditions). Cryo-HS blastocysts exhibited a decreased recovery rate: HSPA1A expression was dramatically increased compared with that in fresh or cryo-con blastocysts at $6 \mathrm{~h}$, and IFNT expression was decreased compared with that in cryo-con blastocysts at 6 $\mathrm{h}$ (both $\mathrm{P}<0.05)$. Cryo-con blastocysts at $6 \mathrm{~h}$ also exhibited higher HSPA1A expression than fresh blastocysts $(\mathrm{P}<0.05)$. At $48 \mathrm{~h}$ after thawing, the number of hatched blastocysts and blastocyst diameter were lower in cryo-HS blastocysts $(\mathrm{P}<0.05)$. Cryo-con blastocysts showed lower POU5F1 levels at $48 \mathrm{~h}$ than fresh, cryo-con or cryo-HS blastocysts at $6 \mathrm{~h}(\mathrm{P}<0.05)$, but their POU5F1 levels were not different from those of cryo-HS blastocysts at $48 \mathrm{~h}$. These results indicated that application of heat shock to frozen-thawed blastocysts was highly damaging. The increase in damage by the interaction of freezing-thawing and heat shock might be one reason for the low conception rate in frozen-thawed embryo transfer in summer.
\end{abstract}

Key words: Blastocysts, Cryopreservation, Heat shock, IVF

(J. Reprod. Dev. 61: 423-429, 2015)

A low conception rate in dairy cows in summer has been reported worldwide and is an important problem [1-4]. It has been suggested that the increase of maternal body temperature in hot climates induces embryonic death and leads to a low pregnancy rate $[5,6]$. Some studies have suggested that a high body temperature on the days of insemination and early pregnancy would be associated with lower conception rates $[3,6,7]$. Both in vivo and in vitro experiments have revealed that early stage embryos are more susceptible to high temperature and more easily damaged by heat shock and decreased viability compared with later stage embryos such as morulae or blastocysts [6, 8-11]. Therefore, it has been suggested that embryo transfer that bypasses the heat-sensitive stage outside of the maternal body would be effective for improving the low conception rate in summer $[12,13]$. Indeed, in vivo fresh embryo transfer has been shown to improve the conception rate of dairy cows under heat stress [14-16]. However, the hormonal reaction of superovulatory cows and the quality of embryos derived from superovulation were lower in summer $[17,18]$. Thus, producing in vivo embryos under

Received: January 19, 2015

Accepted: May 23, 2015

Published online in J-STAGE: June 21, 2015

(C)2015 by the Society for Reproduction and Development

Correspondence: M Sakatani (e-mail: msaka@affrc.go.jp)

This is an open-access article distributed under the terms of the Creative Commons Attribution Non-Commercial No Derivatives (by-nc-nd) License $<$ http://creativecommons.org/licenses/by-nc-nd/3.0/>. heat stress conditions is not effective. Producing embryos in vitro, on the other hand, is effective in summer because the embryos are not affected by heat stress. Moreover, in vitro embryo production is less expensive than the corresponding in vivo process. In recent years, in vitro-derived embryo transfer has been increasingly used throughout the world (2012 International Embryo Transfer Society Reports). Therefore, it is thought that the use of in vitro-derived frozen embryos would contribute to an improvement in the summer conception rate in dairy cows. Freezing destroys the cell organelles and decreases viability. Cryopreservation of blastocysts also decreases embryo viability compared with fresh blastocysts $[19,20]$. To enhance the cryotolerance of embryos, culture conditions and cryopreservation methods have been improved. However, the pregnancy rate of conventional frozen-thawed blastocysts has been shown to be lower than that of fresh embryo transfer not only in embryos cultured in vitro but also in those derived in vivo $[21,22]$. In particular, the summer conception rate by in vitro-cryopreserved embryo transfer remains quite low [14, 23, 24].

In Japan, transferring beef cattle embryos to dairy cattle is a common means of augmenting income among farmers and also avoids accidents associated with delivery in heifers [25]. It is effective for producing thermotolerant embryos that can be implanted after embryo transfer even under high temperatures. However, there have been very few reports about the effect of heat shock after thawing on embryonic viability and proliferation in frozen in vitro-derived blastocysts. Therefore, in this study we focused our attention on the 
use of in vitro-derived beef cattle embryos and investigated the effect of heat shock on embryo viability, proliferation and gene expressions related to embryo quality in conventional frozen-thawed blastocysts.

\section{Materials and Methods}

\section{Chemicals}

Unless otherwise mentioned, all chemicals were purchased from Sigma-Aldrich (Tokyo, Japan).

\section{In vitro production of embryos}

Experiment 1: Abattoir-derived cumulus oocyte complexes (COCs) from 2 to $6 \mathrm{~mm}$ follicles were matured with $5 \%$ fetal bovine serum (FBS; Life Technologies, Tokyo, Japan), 100 IU follicule-stimulating hormone (FSH, Antorin, Denka Pharmaceuticals, Tokyo, Japan) and $0.1 \mathrm{mg} / \mathrm{ml}$ gentamicin supplemented TCM-199 (Life Technologies) at $38.5 \mathrm{C}$ in $5 \% \mathrm{CO}_{2}$ in humidified air for $20 \mathrm{~h}$ without mineral oil ( $50 \mathrm{COCs} / 500 \mu \mathrm{l})$. Then, oocytes were fertilized with frozen-thawed Japanese black bull sperm separated with 90\% Percoll (GE Healthcare Japan, Tokyo, Japan) and diluted with IVF-100 (Research Institute for the Functional Peptides, Yamagata, Japan) to a final concentration of $5.0 \times 10^{6} \mathrm{sperm} / \mathrm{ml}$ for in vitro fertilization at $38.5 \mathrm{C}$ in $5 \% \mathrm{CO}_{2}$ in humidified air for $6 \mathrm{~h}$ ( 20 oocytes/100 $\mu \mathrm{l}$ drop) [26]. Then, putative zygotes were cultured by two different methods to investigate the effect of in vitro production (IVP) methods on the gene expressions of blastocysts.

In the first method (M199), putative zygotes were cultured with cumulus cells in glucose-free modified medium 199 [27] containing $10 \% \mathrm{FBS}, 100 \mathrm{IU} / \mathrm{ml}$ penicillin, and $100 \mu \mathrm{g} / \mathrm{ml}$ streptomycin $(1 \times$ PS) covered with mineral oil (Nacalai Tesque, Tokyo, Japan) at 38.5 $\mathrm{C}$ under $3 \% \mathrm{CO}_{2}, 10 \% \mathrm{O}_{2}$ and $87 \% \mathrm{~N}_{2}(50$ zygotes $/ 500 \mu \mathrm{l})$. On day 6 (day $0=$ day of fertilization) of culture, the culture medium was changed from modified medium 199 to medium 199 containing $10 \% \mathrm{FBS}$ and $1 \times \mathrm{PS}$ at $38.5 \mathrm{C}$ under $3 \% \mathrm{CO}_{2}, 10 \% \mathrm{O}_{2}$ and $87 \% \mathrm{~N}_{2}$.

In the second method (SOF), cumulus cells were removed by repeated mouth pipetting after fertilization. Then, putative zygotes were transferred to an SOF-BE1 drop [28] (30 zygotes/50 $\mu$ l) covered with mineral oil and cultured at $38.5 \mathrm{C}$ with $5 \% \mathrm{O}_{2}, 5 \% \mathrm{CO}_{2}$ and $90 \% \mathrm{~N}_{2}$ in a humidified atmosphere until day 7 .

Experiment 2: The embryos cultured with cumulus cells (coculture) in medium 199 showed higher cryotolerance than the embryos cultured without cumulus cells [29]. Therefore, we used the blastocysts derived from co-culture with M199 in experiment 2.

Approximately 50 abattoir-derived COCs were matured for $20 \mathrm{~h}$ in $500 \mu$ IVMD101 medium (Research Institute for the Functional Peptides) covered with mineral oil. All cultures were maintained at $38.5 \mathrm{C}$ in a humidified atmosphere of $3 \% \mathrm{CO}_{2}, 10 \% \mathrm{O}_{2}$ and $87 \%$ $\mathrm{N}_{2}$. Frozen semen from a Japanese black bull was used for in vitro fertilization, as previously described [30]. The embryos were then cultured with M199 as described in experiment 1.

\section{Cryopreservation and thawing}

Cryopreservation was performed as described in a previous report [30]. Briefly, blastocysts obtained at day 7 were transferred to a cryoprotective solution $(5 \%[\mathrm{v} / \mathrm{v}]$ ethylene glycol, $6 \%[\mathrm{v} / \mathrm{v}]$ propylene glycol, $0.1 \mathrm{M}$ sucrose and $4 \mathrm{mg} / \mathrm{ml}$ bovine serum albumin [BSA] in Dulbecco's phosphate-buffered saline [D-PBS]), and then 1 or 2 blastocysts were introduced into a $0.25-\mathrm{ml}$ straw (IMV Technologies, L'Aigle, France) at 23-25 C for 13 min of equilibration. Straws were directly set in a programmable freezer (Fujihira, Tokyo, Japan) at -7 $\mathrm{C}$, and seeding was manually performed. Subsequently, straws were cooled at a rate of $-0.3 \mathrm{C} / \mathrm{min}$ to $-30 \mathrm{C}$ and then directly transferred to liquid nitrogen for storage until analysis.

The straws were thawed in air for $10 \mathrm{sec}$ and then immersed in a water bath at $30 \mathrm{C}$ for $10 \mathrm{sec}$. Then, embryos were transferred to a culture drop including medium 199 containing $100 \mu \mathrm{M}$ $\beta$-mercaptoethanol, 20\% FBS and $1 \times$ PS.

\section{Quantitative reverse transcriptase-polymerase chain reaction (qRT-PCR)}

Blastocysts were collected and washed with $0.1 \%(\mathrm{w} / \mathrm{v})$ polyvinyl alcohol in D-PBS (0.1\% PVA-PBS) and then transferred into a 0.5 $\mathrm{ml}$ sampling tube with a minimum volume of PVA-PBS and kept at $-80 \mathrm{C}$ until analysis. RNA extraction was performed with an RNeasy Plus Micro Kit (Qiagen, Tokyo, Japan) according to the manufacturer's instructions. Then, the reverse transcription reaction was conducted with reverse transcriptase (SuperScript III; Life Technologies) according to the manufacturer's instructions. The qRT-PCR protocol consisted of 40 cycles of $95 \mathrm{C}$ for $5 \mathrm{sec}, 58 \mathrm{C}$ for $10 \mathrm{sec}$ and $72 \mathrm{C}$ for $10 \mathrm{sec}$, followed by a single denaturing step of 95 $\mathrm{C}$ for $30 \mathrm{sec}$. qRT-PCR was performed using a Chromo4 Real-Time Thermal Cycler (Bio-Rad, Tokyo, Japan) with $20 \mu$ reaction mix containing $10 \mu \mathrm{l}$ of SsoFast EvaGreen Supermix (Bio-Rad), $7 \mu 1$ of water, $2 \mu \mathrm{l}$ of template cDNA and $0.5 \mu \mathrm{l}$ each of the forward or reverse primers of $18 \mathrm{~s}$ ribosomal RNA $(R N 18 S 1)$, heat shock protein $70 \mathrm{kDa}(H S P A 1 A$ [31]), interferon tau (IFNT [31]) and POU domain class 5 transcription factor 1 (Oct4, POU5F1 [32]) (Table 1).

The cycle thresholds of each gene were calculated. Then, the fold changes of target genes were evaluated by the $\Delta \Delta \mathrm{CT}$ method using the reference gene (RN18S1) expression.

\section{Experimental design}

Experiment 1 - Effect of heat shock on in vitro-derived blastocysts: Embryos were derived using two different methods to evaluate the effect of the culture system on gene expressions.

On day 7 at 168 hpi (hours post insemination), blastocysts were exposed at $41.0 \mathrm{C}$ in $5 \% \mathrm{O}_{2}, 5 \% \mathrm{CO}_{2}$ and $90 \% \mathrm{~N}_{2}$ for $6 \mathrm{~h}$ (M199-HS, SOF-HS). Control blastocysts were incubated at $38.5 \mathrm{C}$ in $5 \% \mathrm{O}_{2}$, 5\% $\mathrm{CO}_{2}$ and $90 \% \mathrm{~N}_{2}$ until 174 hpi (M199-con, SOF-con). Then, five expanding or expanded blastocysts from each treatment were collected for real-time qPCR analysis.

Experiment 2 - Effect of heat shock on in vitro-derived frozenthawed blastocysts: On day 7 (at $168 \mathrm{hpi}$ ), blastocysts derived from M199 were cryopreserved and kept in liquid nitrogen until thawing.

On the day of the experiment, straws were thawed and blastocysts were washed with medium 199 containing $100 \mu \mathrm{M}$ of $\beta$-mercaptoethanol, $20 \%$ FBS and $1 \times$ PS. Then, the thawed embryos were incubated for $6 \mathrm{~h}$ at $38.5 \mathrm{C}$ (cryo-con) or $41.0 \mathrm{C}$ (cryo-HS) with medium 199 containing $\beta$-mercaptoethanol, 20\% FBS, and $1 \times \mathrm{PS}$ in a $2.0 \mathrm{ml}$ microtube ( 3 to 5 thawed embryos $/ 500 \mu \mathrm{l}$ ) with a closed lid in a thermostatic chamber (MD-MINI dry bath; Major Science, Pan-chiao, Taiwan). The culture medium was equilibrated 
Table 1. Primer information

\begin{tabular}{llccc}
\hline \multicolumn{1}{c}{ Gene } & \multicolumn{1}{c}{ Sequence (5'-3') } & Product length & Accession number & References \\
\hline RN18S1 & $\begin{array}{l}\text { F: AAACGGCTACCACATCCAAGG } \\
\text { R: GCGGAAGGATTTAAAGTGGACTC }\end{array}$ & 138 & DQ066896 & \\
\hline HSPA1A & $\begin{array}{l}\text { F: GACAAGTGCCAGGAGGTGATTT } \\
\text { R: CAGTCTGCTGATGATGGGGTTA }\end{array}$ & 117 & U09861 & [31] \\
\hline IFNT & $\begin{array}{l}\text { F: TCCATGAGATGCTCCAGCAGT } \\
\text { R: TGTTGGAGCCCAGTGCAGA }\end{array}$ & 103 & X65539 & [31] \\
\hline POU5F1 & $\begin{array}{l}\text { F: TGCAGCAAATTAGCCACATC } \\
\text { R: AATCCTCACGTTGGGAGTTG }\end{array}$ & 123 & NM_174580.2 & {$[32]$} \\
\hline
\end{tabular}

Table 2. Effect of heat shock on blastocysts without cryopreservation

\begin{tabular}{lcrc}
\hline \multirow{2}{*}{ Treatment } & $\begin{array}{c}\mathrm{n} \\
\text { (replicates) }\end{array}$ & \multicolumn{2}{c}{$\begin{array}{c}\text { Number of blastocysts at 6 h after } \\
\text { heat shock (\%) }\end{array}$} \\
\cline { 3 - 4 } & & Shrunken & Normal (developing) \\
\hline M199-con & $38(5)$ & $10(26.3)$ & $28(73.7)$ \\
M199-HS & $38(5)$ & $4(10.5)$ & $34(89.5)$ \\
SOF-con & $40(5)$ & $7(17.5)$ & $33(82.5)$ \\
SOF-HS & $40(5)$ & $4(10.0)$ & $36(90.0)$ \\
\hline
\end{tabular}

at $38.5 \mathrm{C}$ in a humidified atmosphere of $3 \% \mathrm{CO}_{2}, 10 \% \mathrm{O}_{2}$ and $87 \%$ $\mathrm{N}_{2}$ prior to incubation.

Blastocyst morphologies were observed after $6 \mathrm{~h}$ of incubation. Then, five re-expanding or re-expanded blastocysts (Cryo-HS includes shrunken blastocysts because of a very low recovery rate) per replicate were collected for gene expression analysis. The rest of the heat-shocked blastocysts were moved to the incubator at $38.5 \mathrm{C}$ in a humidified atmosphere of $5 \% \mathrm{CO}_{2}$ in air, and then the recovery culture was continued until $48 \mathrm{~h}$ after thawing. The viability and diameters of blastocysts were analyzed, and three of the hatched-blastocysts from each replicate were collected for gene expression analysis.

\section{Statistical analysis}

Experiments were replicated at least five times in experiment 1 and three times in experiment 2. One-way analysis of variance (ANOVA) was used to determine significant differences between groups for the gene expression analysis, followed by the Tukey-Kramer test (StatView program Ver. 5.0; Abacus Concepts, Berkeley, CA, USA). Data for embryo viability at $6 \mathrm{~h}$ after heat shock or thawing were analyzed using chi-square analysis and residual analysis (StatView). Data for the embryos hatched at $48 \mathrm{~h}$ after thawing were analyzed by Fisher's exact test (StatView). The diameters of surviving blastocysts at $48 \mathrm{~h}$ after thawing were analyzed by Student's $t$-test (StatView). A P value of $<0.05$ was considered statistically significant.

\section{Results}

\section{Experiment 1}

There were no significant differences in blastocysts rate between the two culture methods (data not shown). The numbers of shrunken embryos and normal developed embryos after heat shock are shown in Table 2. Most blastocysts were developed after $6 \mathrm{~h}$ of heat shock without cryopreservation, some blastocysts had shrunken blastocoels. No effects of heat shock were observed on the numbers of shrunken blastocysts and surviving embryos (Table 2).

A total of 25 blastocysts that had developed beyond the expanding or expanded stage in each of the five replicates for each treatment (five blastocysts/replicate) were analyzed for gene expression. Gene expressions after heat shock are shown in Fig. 1. Data are shown as the gene expression relative to M199-con (M199-con =1). There were no significant differences in any genes between media. However, after $6 \mathrm{~h}$ of heat shock, the HSPA1A expression was dramatically increased in heat-shocked blastocysts compared with control blastocysts $(\mathrm{P}<$ 0.05 , Fig. 1A). The IFNT and POU5F1 expressions were not affected by heat shock (Figs. 1B and C).

\section{Experiment 2}

Embryonic viability: A total of 34 blastocysts in each of the four replicates for each treatment were evaluated with regard to recovery after thawing. The numbers of embryos recovered and images of blastocysts at $6 \mathrm{~h}$ after thawing are shown in Table 2 and Fig. 2, respectively. More than $90 \%$ of all blastocysts were re-expanding or re-expanded under the cryo-con conditions at $6 \mathrm{~h}$ (Table 3, Fig. 2). However, $44 \%$ of the blastocysts under the cryo-HS conditions at $6 \mathrm{~h}$ were not recovered $(\mathrm{P}<0.01$, Table 3$)$, and fewer blastocysts from the heat shock treatment were re-expanded than under the control conditions $(\mathrm{P}<0.05$, Table 3, Fig. 2).

A total of 14 blastocysts in each of the three replicates for each treatment were cultured until $48 \mathrm{~h}$ and evaluated for embryo recovery and morphology. The numbers of embryos recovered after $48 \mathrm{~h}$ of thawing are shown in Table 3 and Fig. 2, respectively. Cryo-HS blastocysts at $48 \mathrm{~h}$ showed a lower hatching rate (14.3\%) compared with the cryo-con blastocysts at $48 \mathrm{~h}(64.3 \%$; $\mathrm{P}<0.05$, Table 4$)$. Even among the blastocysts that survived the heat shock, the diameter of the cryo-HS blastocysts was significantly lower than that of the cryo-con blastocysts at $48 \mathrm{~h}(\mathrm{P}<0.05$, Table 4 , Fig. 2$)$.

Gene expression: Five blastocysts from each of the 4 replicates from each treatment group at $6 \mathrm{~h}$ after thawing and 3 recovered blastocysts from each of the 3 replicates from each treatment group at $48 \mathrm{~h}$ were used for gene expression analysis. Each synthesized cDNA was diluted with RNase- and DNase-free water depending on the number of blastocysts to adjust the volume per blastocyst $(10 \mu \mathrm{l} /$ 
A

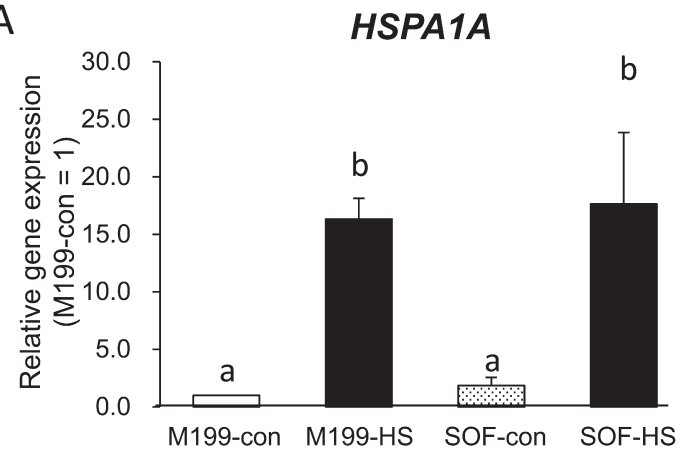

B

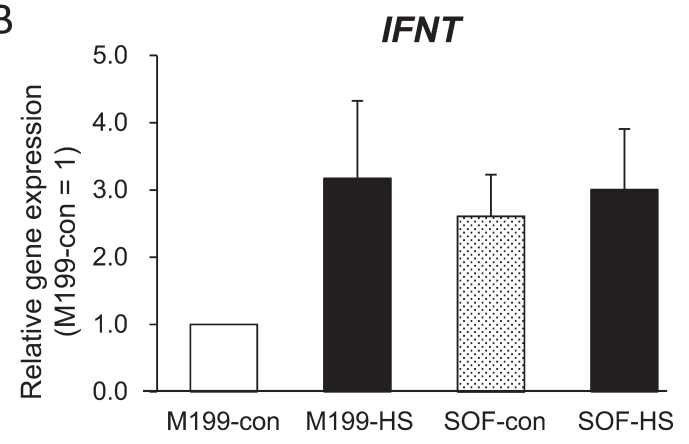

C

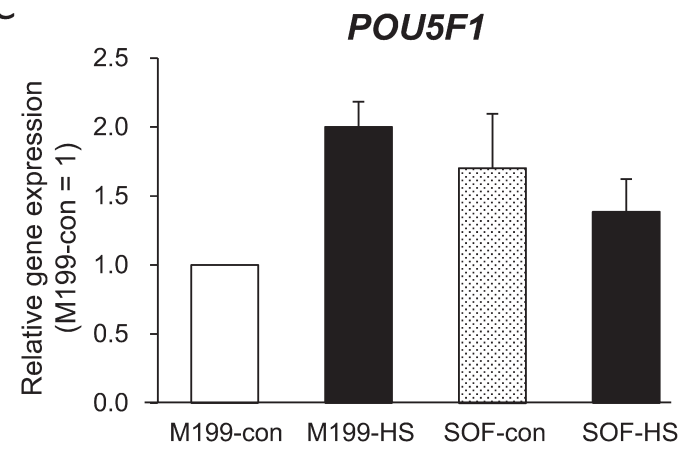

Fig. 1. Effect of heat shock applied to fresh blastocysts on gene expression. Gene expressions of blastocysts at 174 hpi. Heat shock protein $70 \mathrm{kDa}(H S P A 1 A, \mathrm{~A})$, interferon tau $(I F N T, \mathrm{~B})$ and POU domain, class 5, transcription factor 1 (POU5F1, C). Results are means \pm SEM of fold changes relative to M199 culture at 38.5 C $($ M199-con $=1)$. White bars and polka-dot bars represent blastocysts cultured at 38.5 C (M199-con and SOFcon, respectively), and black bars represent blastocysts exposed to $41.0 \mathrm{C}$ for $6 \mathrm{~h}$ as heat shock (M199-HS, SOF-HS). Different letters above bars indicate $\mathrm{P}<0.05$.

blastocyst). The fold changes of real-time qPCR results are shown in Figure 3. Data were compared with fresh blastocysts (collected at $174 \mathrm{hpi}$ without cryopreservation and heat shock, fold change of $1=$ fresh). Interestingly, cryopreservation without heat shock (cryo-con at 6 h) showed higher HSPA1A expression compared with fresh blastocysts $(\mathrm{P}<0.05)$. Moreover, HSPA1A expression was dramatically increased by heat shock (cryo HS at $6 \mathrm{~h}, \mathrm{P}<0.05$ ). However, the HSPA1A levels returned to the levels in fresh blastocysts after $48 \mathrm{~h}$
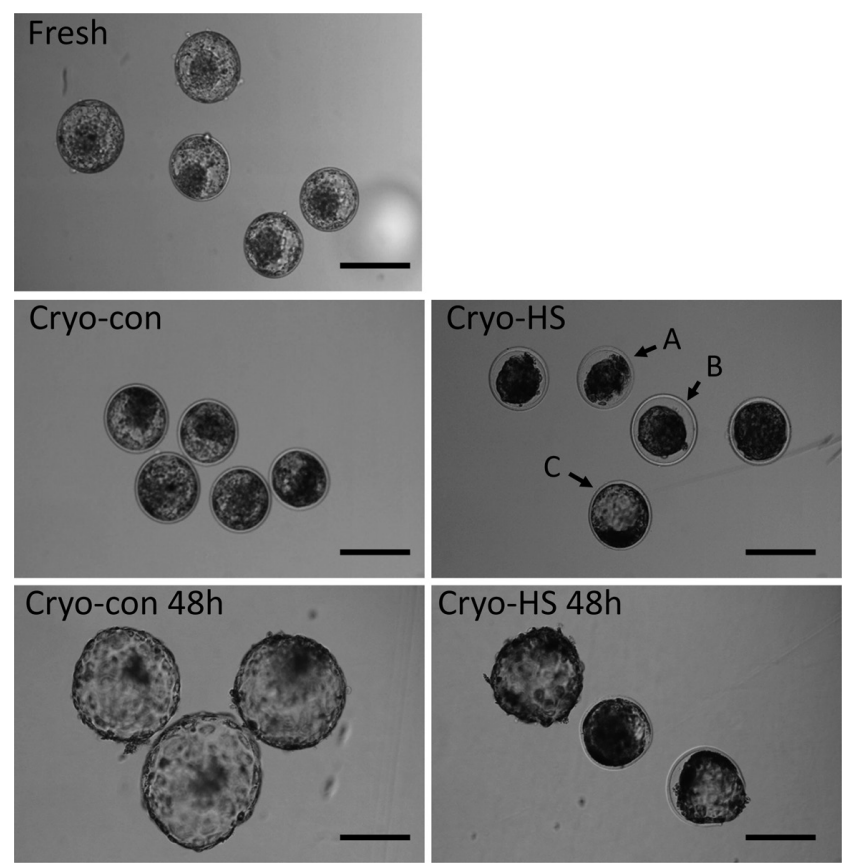

Fig. 2. Representative images of embryos exposed to heat shock in experiment 2. Fresh: blastocysts on day 7 (at $168 \mathrm{hpi}$ ) derived from the second method (M199). Cryo-con: blastocysts incubated at $38.5 \mathrm{C}$ for $6 \mathrm{~h}$ after thawing. Cryo-HS: blastocysts cultured at $41.0 \mathrm{C}$ for $6 \mathrm{~h}$ after thawing. Cryo-con $48 \mathrm{~h}$ : blastocysts incubated at $38.5 \mathrm{C}$ for $48 \mathrm{~h}$ after thawing. Cryo-HS $48 \mathrm{~h}$ : blastocysts exposed at $41.0 \mathrm{C}$ for $6 \mathrm{~h}$ and then cultured at $42 \mathrm{~h}$ at $38.5 \mathrm{C}$ (magnification, $\times 100$; scale bar, $200 \mu \mathrm{m}$ ). A: Shrunken (no reexpansion of blastocoel). B: Expanding (re-expanding blastocoel but not completely filling the blasotcyst and reaching the zona pellucida). C: Expanded (recovered to expanded blastocyst).

Table 3. Effect of heat shock on blastocyst survival at $6 \mathrm{~h}$ after thawing (after heat shock)

\begin{tabular}{lcccc}
\hline \multirow{2}{*}{ Treatment } & \multirow{n}{n}{} & \multicolumn{3}{c}{ Number of blastocysts at 6 h after thawing (\%) } \\
\cline { 3 - 5 } & (replicates) & Shrunken & Expanding & Expanded \\
\hline Cryo-con & $34(4)$ & $3(8.9)^{\mathrm{a}}$ & $14(41.2)$ & $17(50.0)^{\mathrm{a}}$ \\
Cryo-HS & $34(4)$ & $15(44.1)^{\mathrm{b}}$ & $12(35.3)$ & $7(20.6)^{\mathrm{c}}$ \\
\hline
\end{tabular}

Values with different symbols are significantly different (a, b $\mathrm{P}<0.01$; a, c $\mathrm{P}<0.05)$.

Table 4. Effect of heat shock on blastocyst survival and size at $48 \mathrm{~h}$ after thawing

\begin{tabular}{lccc}
\hline Treatment & $\begin{array}{c}\mathrm{n} \\
\text { (replicates) }\end{array}$ & $\begin{array}{c}\text { Number of hatched } \\
\text { blastocysts at 48 h after } \\
\text { thawing }(\%)\end{array}$ & $\begin{array}{c}\text { Diameter of } \\
\text { blastocysts }(\mu \mathrm{m})^{*}\end{array}$ \\
\hline Cryo-con & $14(3)$ & $9(64.3)^{\mathrm{a}}$ & $279.4 \pm 79.7^{\mathrm{a}}$ \\
Cryo-HS & $14(3)$ & $2(14.3)^{\mathrm{b}}$ & $215.3 \pm 63.0^{\mathrm{b}}$ \\
\hline
\end{tabular}

* Excluding degenerated blastocysts (Cryo-con, average of 13 blastocysts; Cryo-HS, average of 10 blastocysts). Values with different symbols are significantly different $(\mathrm{a}, \mathrm{b} \mathrm{P}<0.05)$. 
A

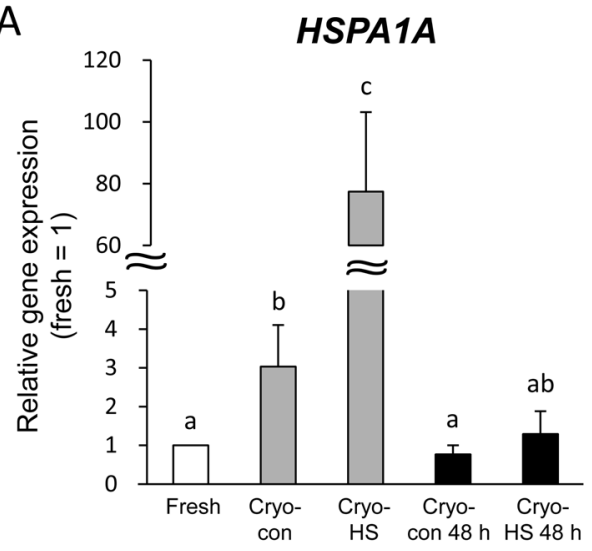

B

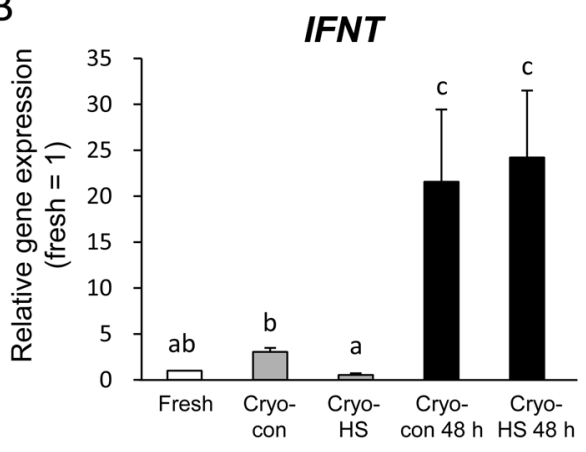

C

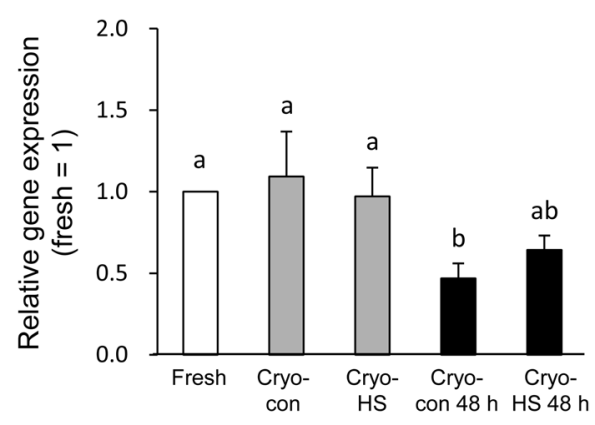

Fig. 3. Effect of heat shock applied to frozen-thawed blastocysts on gene expression. Results are means \pm SEM of the fold change relative to fresh blastocysts. Heat shock protein $70 \mathrm{kDa}$ (HSPA1A, A), interferon tau $(I F N T, \mathrm{~B})$ and POU domain, class 5, transcription factor 1 (POU5F1, C). Cryo-con: blastocysts incubated at 38.5 $\mathrm{C}$ for $6 \mathrm{~h}$ after thawing. Cryo-HS: blastocysts incubated at 41.0 $\mathrm{C}$ for $6 \mathrm{~h}$ after thawing. Cryo-con $48 \mathrm{~h}$ : blastocysts incubated at $38.5 \mathrm{C}$ for $48 \mathrm{~h}$ after thawing. Cryo-HS at $48 \mathrm{~h}$ : blastocysts exposed at $41.0 \mathrm{C}$ for $6 \mathrm{~h}$ and then cultured at $38.5 \mathrm{C}$ for $42 \mathrm{~h}$. Different letters above bars indicate $\mathrm{P}<0.05$.

of thawing both in the cryo-con blastocysts at $48 \mathrm{~h}$ and the cryo-HS blastocysts at $48 \mathrm{~h}$ (Fig. 3A).

The IFNT level was not different between the fresh and cryo-con blastocysts at $6 \mathrm{~h}$. But cryo-HS blastocysts at $6 \mathrm{~h}$ showed lower IFNT expression than cryo-con blastocysts at $6 \mathrm{~h}(\mathrm{P}<0.05$, Fig. $3 \mathrm{~B})$. Recovered blastocysts at $48 \mathrm{~h}$ after thawing showed significantly higher IFNT levels than those collected at $174 \mathrm{hpi}$ (fresh, cryo-con at $6 \mathrm{~h}$ and cryo-HS at $6 \mathrm{~h}, \mathrm{P}<0.05$, Fig. 3B). There was no difference between cryo-con and cryo-HS blastocysts at $48 \mathrm{~h}$.

POU 5F1 levels were significantly lower in cryo-con blastocysts at $48 \mathrm{~h}$ compared with those collected at $174 \mathrm{hpi}$ (fresh, cryo-con at $6 \mathrm{~h}$ and cryo-HS at $6 \mathrm{~h}, \mathrm{P}<0.05$, Fig. $3 \mathrm{C}$ ). But the POU $5 F 1$ levels of the cryo-HS blastocysts at $48 \mathrm{~h}$ were no different from those of other groups (fresh, cryo-con at $6 \mathrm{~h}$ and cryo-HS at $6 \mathrm{~h}$, Fig. 3C).

\section{Discussion}

This study aimed to understand the reasons for conception failure after the transfer of frozen bovine embryos in summer. To this end, we evaluated the effects of heat shock on frozen-thawed IVP blastocyst viability and gene expressions related to stress, embryo quality and pregnancy recognition. A temperature of $41 \mathrm{C}$ for $6 \mathrm{~h}$ was used as the heat shock treatment, since it reflects the daytime body temperature of Holstein cows in summer [3, 33].

In the present study, no differences in embryo development and gene expressions were observed between the culture media in experiment 1 . Heat shock induced HSPA1A expression in both fresh (M199-HS and SOF-HS) and frozen-thawed (cryo-HS) blastocysts (Figs. 1A and 3A). HSPA1A is one of the important stress markers of cells. Many studies have demonstrated that heat shock induces HSPA1A expression in bovine embryos including blastocysts [34-37]. In experiment 2, HSPA1A expression in frozen-thawed blastocysts without heat shock (cryo-con at $6 \mathrm{~h}$ ) was increased compared with that in fresh blastocysts. It has been reported that cell organelles were damaged and viability was decreased in frozen-thawed blastocysts compared with fresh blastocysts $[19,20]$. DNA fragmentation, apoptosis and higher HSPA1A expression were also observed in frozen-thawed blastocysts [38]. Our present finding of an increase in HSPA1A in cryo-con blastocysts at $6 \mathrm{~h}$ was in good agreement with these previous reports and suggested that the freezing and thawing process increased the damage to the blastocysts. The remarkable increase of HSPA1A in cryo-HS blastocysts at $6 \mathrm{~h}$ is likely due to the interaction between the freezing-thawing process and heat shock. Although no effect of heat shock was observed on the rate of shrunken blastocysts in experiment 1 , our viability data at $6 \mathrm{~h}$ after thawing showed that about $40 \%$ of cryo-HS blastocysts were still shrunken and that the number of re-expanded blastocysts in the cryo-HS group was significantly lower than that in the cryo-con group. In addition, the cryo-HS conditions resulted in a lower number of hatched blastocysts and lower diameter of blastocysts than the cryo-con conditions even after $48 \mathrm{~h}$ of recovery culture. These results indicate that the heat shock after the freezing-thawing process caused severe impairment of blastocysts. In contrast, HSPA1A expression returned to the same levels as in fresh or cryo-con blastocysts after $48 \mathrm{~h}$ in the blastocysts that survived heat shock and were re-hatching or already re-hatched at $48 \mathrm{~h}$ after thawing. This suggests that HSPA1A expression was transiently elevated just after heat shock and decreased continuously with time.

IFN tau is a type I interferon and acts as an important signaling molecule during pregnancy in ruminants $[39,40]$. IFN tau secretion is increased notably at more than 12 days after pregnancy in cattle, but the IFN tau gene is already expressed in day 7 blastocysts and 
thus is used as a marker of embryo quality [40-42]. A decrease in the IFN tau concentration leads to failure of pregnancy, and dairy cows with a pregnancy rate is low in summer show lower IFN tau secretion [43].

Hickman et al. reported that IFNT expression in heat-shocked blastocysts was increased [37]. In the present study, however, IFNT expression was not affected by heat shock in blastocysts without cryopreservation (experiment 1), and IFNT expression was significantly decreased in the cryo-HS group at $6 \mathrm{~h}$ post thawing. It is considered that IFNT expression or secretion would be directly affected by the cell number or damage to the trophectoderm because the trophectoderm mainly secretes IFN tau in fetuses [40]. In experiment 1 of the present study, the heat shock treatment consisted of $41 \mathrm{C}$ for $6 \mathrm{~h}$, which was milder than that in Hickman's experiment (42 C for $4 \mathrm{~h}$ ). Also, the sampling of blastocyst stages did not differ between the treatments in experiment 1 , and no significant differences in embryonic morphologies were observed in heat-shocked blastocysts. Therefore, IFNT expression was not changed in experiment 1. Correa et al. reported that no IFNT increase was observed in embryos cultured under a high oxygen concentration. This evidence also supported the results of our experiment 1 [41].

On the other hand, more than $40 \%$ of cryo-HS blastocysts at $6 \mathrm{~h}$ were still shrinking in experiment 2 , and there were very few re-expanded blastocysts compared with under the cryo-con conditions at $6 \mathrm{~h}$ (Table 3). Moreover, the collected samples of cryo-HS blastocysts at $6 \mathrm{~h}$ included some shrunken blastocysts. This may have indicated that the cryo-HS samples had low numbers of living cells and that heat shock after freeze-thawing damaged the trophectoderm. Therefore, it is possible that the IFNT expression in cryo-HS blastocysts at $6 \mathrm{~h}$ was decreased because of the low quality and the number of living cells in the trophectoderm. IFNT expressions at $48 \mathrm{~h}$ after thawing were dramatically increased both in cryo-con blastocysts at $48 \mathrm{~h}$ and cryo-HS blastocysts at $48 \mathrm{~h}$. This indicated that most of the collected blastocysts at $48 \mathrm{~h}$ were hatching or hatched blastocysts, and these blastocysts had a much higher number of trophectoderm cells contributing to IFN tau secretion than those at $6 \mathrm{~h}$ after thawing. In this study, we did not count the number of cells in blastocysts. However, Leidenfrost et al. compared the cell numbers of bovine non-expanded, expanded and hatched blastocysts and reported that the total number of cells nad number of cells in the trophectoderm increased depending on the blastocysts stage but that the number of cells in the ICM was not affected by the blastocysts stage [44]. Another study reported a correlation between total cell number and the diameter of blastocysts [45]. This indicated that the total cell numbers of blastocysts were inferable from the diameter of the blastocysts. Therefore, the blastocysts collected at $48 \mathrm{~h}$ after thawing would have a higher number of cells in the trophectoderm and increased IFNT expression.

$P O U 5 F 1$, which is mainly expressed in the ICM of blastocysts, is used not only as a pluripotency marker but also as a marker of embryo quality. POU5F1 expressions were not changed at $6 \mathrm{~h}$ of heat shock in experiments 1 and 2. Although cryo-con blastocysts at $48 \mathrm{~h}$ after thawing exhibited significantly decreased POU5F1 expression compared with fresh, cryo-con and cryo-HS blastocysts at $6 \mathrm{~h}, P O U 5 F 1$ expression in cryo-HS blastocysts at $48 \mathrm{~h}$ was not different from other groups (fresh, cryo-con at $6 \mathrm{~h}$ and cryo-HS at 6 h). As mentioned above, blastocysts collected at $48 \mathrm{~h}$ after thawing were mostly hatching or hatched. The number of trophectoderm or primitive endoderm cells increased continuously with blastocyst growth [44]. As a consequence, the ratio of the ICM to total cell number decreased. The fold changes in POU5F1 expression were calculated relatice to the expression of inner standard genes ( $R N 18 S 1)$ by the $\triangle \triangle \mathrm{CT}$ method. Therefore, it is likely that POU5F1 expression in cryo-con blastocysts at $48 \mathrm{~h}$ would decrease along with a decrease in the ratio of the ICM to total cell number. The number of blastocysts hatched and the diameter of cryo-HS blastocysts at $48 \mathrm{~h}$ were smaller than those of cryo-con blastocysts at $48 \mathrm{~h}$ (Table 3 and 4). This suggested that proliferation of the trophectoderm or primitive endoderm was inhibited or delayed under heat shock conditions, and the ICM to total cell number ratio was higher than that of cryo-con blastocysts at $48 \mathrm{~h}$. Therefore, it is possible that POU $5 F 1$ expression in cryo-HS blastocysts at $48 \mathrm{~h}$ was not decreased as much as in cryo-con blastocysts at $48 \mathrm{~h}$.

In conclusion, the present study suggested that application of heat shock to frozen-thawed blastocysts induced higher levels of cell stress, damage and greater decreases in viability and embryonic quality via an interaction between the freezing-thawing process and heat shock. Even among the blastocysts that survived the heat shock, recovery at $48 \mathrm{~h}$ was delayed, and growth was inhibited. These results indicated that heat-shock damage would cause a low conception rate in blastocysts subjected to frozen-thawed embryo transfer during summer. Further research will be needed before frozen-thawed embryo transfer can be applied to improve the low conception rate of cows in summer, such as by producing thermotolerant frozen embryos.

\section{Acknowledgments}

The authors thank Ms Michie Teramoto and Ms Kimiko Miyaji for their experimental assistance. Special thanks are extended to the Fukuoka and Kumamoto Meat Trading Center and the Fukuoka and Kumamoto Prefecture Meat Inspection Office for providing ovaries.

This project was supported by an Ito Foundation Research Grant (Grant \#: 2014-25).

The authors declare that there is no conflict of interest that could be perceived as prejudicing the impartiality of the research reported.

\section{References}

1. Collier RJ, Dahl GE, VanBaale MJ. Major advances associated with environmental effects on dairy cattle. J Dairy Sci 2006; 89: 1244-1253. [Medline] [CrossRef]

2. García-Ispierto I, López-Gatius F, Bech-Sabat G, Santolaria P, Yániz JL, Nogareda C, De Rensis F, López-Béjar M. Climate factors affecting conception rate of high producing dairy cows in northeastern Spain. Theriogenology 2007; 67: 1379-1385. [Medline] [CrossRef]

3. Nabenishi H, Ohta H, Nishimoto T, Morita T, Ashizawa K, Tsuzuki Y. Effect of the temperature-humidity index on body temperature and conception rate of lactating dairy cows in southwestern Japan. J Reprod Dev 2011; 57: 450-456. [Medline] [CrossRef]

4. Villa-Mancera A, Méndez-Mendoza M, Huerta-Crispín R, Vázquez-Flores F, Córdova-Izquierdo A. Effect of climate factors on conception rate of lactating dairy cows in Mexico. Trop Anim Health Prod 2011; 43: 597-601. [Medline] [CrossRef]

5. Putney DJ, Mullins S, Thatcher WW, Drost M, Gross TS. Embryonic development in superovulated dairy cattle exposed to elevated ambient temperatures between the onset of estrus and insemination. Anim Reprod Sci 1989; 19: 37-51. [CrossRef] 
6. Ealy AD, Drost M, Hansen PJ. Developmental changes in embryonic resistance to adverse effects of maternal heat stress in cows. J Dairy Sci 1993; 76: 2899-2905. [Medline] [CrossRef]

7. Moghaddam A, Karimi I, Pooyanmehr M. Effects of short-term cooling on pregnancy rate of dairy heifers under summer heat stress. Vet Res Commun 2009; 33: 567-575. [Medline] [CrossRef]

8. Edwards JL, Hansen PJ. Differential responses of bovine oocytes and preimplantation embryos to heat shock. Mol Reprod Dev 1997; 46: 138-145. [Medline] [CrossRef]

9. Rivera RM, Hansen PJ. Development of cultured bovine embryos after exposure to high temperatures in the physiological range. Reproduction 2001; 121: 107-115. [Medline] [CrossRef]

10. Hansen PJ. Embryonic mortality in cattle from the embryo's perspective. J Anim Sci 2002; 80: E33-E44.

11. Sakatani M, Kobayashi S, Takahashi M. Effects of heat shock on in vitro development and intracellular oxidative state of bovine preimplantation embryos. Mol Reprod Dev 2004; 67: 77-82. [Medline] [CrossRef]

12. Hansen PJ, Aréchiga CF. Strategies for managing reproduction in the heat-stressed dairy cow. J Anim Sci 1999; 77(Suppl 2): 36-50. [Medline]

13. Rutledge JJ. Use of embryo transfer and IVF to bypass effects of heat stress. Theriogenology 2001; 55: 105-111. [Medline] [CrossRef]

14. Drost M, Ambrose JD, Thatcher MJ, Cantrell CK, Wolfsdorf KE, Hasler JF, Thatcher WW. Conception rates after artificial insemination or embryo transfer in lactating dairy cows during summer in Florida. Theriogenology 1999; 52: 1161-1167. [Medline] [CrossRef]

15. Al-Katanani YM, Drost M, Monson RL, Rutledge JJ, Krininger CE 3rd, Block J, Thatcher WW, Hanse PJ. Pregnancy rates following timed embryo transfer with fresh or vitrified in vitro produced embryos in lactating dairy cows under heat stress conditions. Theriogenology 2002; 58: 171-182. [Medline] [CrossRef]

16. Block J, Drost M, Monson RL, Rutledge JJ, Rivera RM, Paula-Lopes FF, Ocon OM, Krininger CE 3rd, Liu J, Hansen PJ. Use of insulin-like growth factor-I during embryo culture and treatment of recipients with gonadotropin-releasing hormone to increase pregnancy rates following the transfer of in vitro-produced embryos to heat-stressed, lactating cows. J Anim Sci 2003; 81: 1590-1602. [Medline]

17. Dobson H, Tebble JE, Smith RF, Ward WR. Is stress really all that important? Theriogenology 2001; 55: 65-73. [Medline] [CrossRef]

18. Hansen PJ, Drost M, Rivera RM, Paula-Lopes FF, al-Katanani YM, Krininger CE 3rd, Chase CC Jr. Adverse impact of heat stress on embryo production: causes and strategies for mitigation. Theriogenology 2001; 55: 91-103. [Medline] [CrossRef]

19. Fair T, Lonergan P, Dinnyes A, Cottell DC, Hyttel P, Ward FA, Boland MP. Ultrastructure of bovine blastocysts following cryopreservation: effect of method of blastocyst production. Mol Reprod Dev 2001; 58: 186-195. [Medline] [CrossRef]

20. Moreira da Silva F, Metelo R. Relation between physical properties of the zona pellucida and viability of bovine embryos after slow-freezing and vitrification. Reprod Domest Anim 2005; 40: 205-209. [Medline] [CrossRef]

21. Agca Y, Monson RL, Northey DL, Mazni OA, Schaefer DM, Rutledge JJ. Transfer of fresh and cryopreserved IVP bovine embryos: normal calving, birth weight and gestation lengths. Theriogenology 1998; 50: 147-162. [Medline] [CrossRef]

22. Chebel RC, Demétrio DGB, Metzger J. Factors affecting success of embryo collection and transfer in large dairy herds. Theriogenology 2008; 69: 98-106. [Medline] [CrossRef]

23. Ambrose JD, Drost M, Monson RL, Rutledge JJ, Leibfried-Rutledge ML, Thatcher MJ, Kassa T, Binelli M, Hansen PJ, Chenoweth PJ, Thatcher WW. Efficacy of timed embryo transfer with fresh and frozen in vitro produced embryos to increase pregnancy rates in heat-stressed dairy cattle. J Dairy Sci 1999; 82: 2369-2376. [Medline] [CrossRef]

24. Stewart BM, Block J, Morelli P, Navarette AE, Amstalden M, Bonilla L, Hansen PJ, Bilby TR. Efficacy of embryo transfer in lactating dairy cows during summer using fresh or vitrified embryos produced in vitro with sex-sorted semen. J Dairy Sci 2011; 94: 3437-3445. [Medline] [CrossRef]

25. Tani M, Hayashida T, Tomokawa K, Mito Y, Funakoshi D, Tani C, Sakatani M, Takahashi M, Kitahara G, Kamimura S. Effect of embryo transfer following artificial insemination (ETFAI) on reproductive performance in dairy cows in South-Western Japan. J Vet Med Sci 2010; 72: 627-629. [Medline] [CrossRef]

26. Sakatani M, Yamanaka K, Kobayashi S, Takahashi M. Heat shock-derived reactive oxygen species induce embryonic mortality in in vitro early stage bovine embryos. $J$ Reprod Dev 2008; 54: 496-501. [Medline] [CrossRef]

27. Mori M, Kasa S, Hattori MA, Ueda S. Development of a single bovine embryo improved by co-culture with trophoblastic vesicles in vitamin-supplemented medium. J Reprod Dev 2012; 58: 717-721. [Medline] [CrossRef]

28. Fields SD, Hansen PJ, Ealy AD. Fibroblast growth factor requirements for in vitro development of bovine embryos. Theriogenology 2011; 75: 1466-1475. [Medline] [CrossRef]

29. Imai K, Matoba S, Dochi O, Shimohira I. Different factors affect developmental competence and cryotolerance in in vitro produced bovine embryo. J Vet Med Sci 2002; 64: 887-891. [Medline] [CrossRef]

30. Mori M, Kuwano T, Kamori T, Isozaki Y, Nishihara T, Yamauchi N, Hattori MA Effect of ATP-binding cassette subfamily B member 1 on bovine blastocyst implantation. Theriogenology 2014; 81: 683-688. [Medline] [CrossRef]

31. Sagirkaya H, Misirlioglu M, Kaya A, First NL, Parrish JJ, Memili E. Developmental and molecular correlates of bovine preimplantation embryos. Reproduction 2006; 131: 895-904. [Medline] [CrossRef]

32. Ozawa M, Sakatani M, Hankowski KE, Terada N, Dobbs KB, Hansen PJ. Importance of culture conditions during the morula-to-blastocyst period on capacity of inner cell-mass cells of bovine blastocysts for establishment of self-renewing pluripotent cells. Theriogenology 2012; 78: 1243-1250: e1-e2. [Medline] [CrossRef]

33. Dikmen S, Cole JB, Null DJ, Hansen PJ. Heritability of rectal temperature and genetic correlations with production and reproduction traits in dairy cattle. J Dairy Sci 2012; 95 3401-3405. [Medline] [CrossRef]

34. Edwards JL, Ealy AD, Monterroso VH, Hansen PJ. Ontogeny of temperature-regulated heat shock protein 70 synthesis in preimplantation bovine embryos. Mol Reprod Dev 1997 48: 25-33. [Medline] [CrossRef]

35. Chandolia RK, Peltier MR, Tian W, Hansen PJ. Transcriptional control of development, protein synthesis, and heat-induced heat shock protein 70 synthesis in 2-cell bovine embryos. Biol Reprod 1999; 61: 1644-1648. [Medline] [CrossRef]

36. Sakatani M, Alvarez NV, Takahashi M, Hansen PJ. Consequences of physiologica heat shock beginning at the zygote stage on embryonic development and expression of stress response genes in cattle. J Dairy Sci 2012; 95: 3080-3091. [Medline] [CrossRef]

37. Hickman CF, Clinton M, Ainslie A, Ashworth CJ, Rooke JA. Heat shock induces interferon-TAU gene expression by in vitro-produced bovine blastocysts. Am J Reprod Immunol 2013; 70: 177-181. [Medline] [CrossRef]

38. Park SY, Kim EY, Cui XS, Tae JC, Lee WD, Kim NH, Park SP, Lim JH. Increase in DNA fragmentation and apoptosis-related gene expression in frozen-thawed bovine blastocysts. Zygote 2006; 14: 125-131. [Medline] [CrossRef]

39. Imakawa K, Anthony RV, Kazemi M, Marotti KR, Polites HG, Roberts RM. Interferon-like sequence of ovine trophoblast protein secreted by embryonic trophectoderm. Nature 1987; 330: 377-379. [Medline] [CrossRef]

40. Bazer FW. Pregnancy recognition signaling mechanisms in ruminants and pigs. J Anim Sci Biotechnol 2013; 4: 23-32. [Medline] [CrossRef]

41. Corrêa GA, Rumpf R, Mundim TCD, Franco MM, Dode MAN. Oxygen tension during in vitro culture of bovine embryos: effect in production and expression of genes related to oxidative stress. Anim Reprod Sci 2008; 104: 132-142. [Medline] [CrossRef]

42. Rizos D, Gutiérrez-Adán A, Pérez-Garnelo S, De La Fuente J, Boland MP, Lonergan P. Bovine embryo culture in the presence or absence of serum: implications for blastocys development, cryotolerance, and messenger RNA expression. Biol Reprod 2003; 68 236-243. [Medline] [CrossRef]

43. Putney DJ, Malayer JR, Gross TS, Thatcher WW, Hansen PJ, Drost M. Heat stress-induced alterations in the synthesis and secretion of proteins and prostaglandins by cultured bovine conceptuses and uterine endometrium. Biol Reprod 1988; 39: 717-728. [Medline] [CrossRef]

44. Leidenfrost S, Boelhauve M, Reichenbach M, Güngör T, Reichenbach HD, Sinowatz F, Wolf E, Habermann FA. Cell arrest and cell death in mammalian preimplantation development: lessons from the bovine model. PLoS ONE 2011; 6: e22121. [Medline] [CrossRef]

45. Mori M, Otoi T, Suzuki T. Correlation between the cell number and diameter in bovin embryos produced in vitro. Reprod Domest Anim 2002; 37: 181-184. [Medline] [CrossRef] 